\title{
Diagnosing of Sustainable Competitive Advantage Using Six Sigma Methodology
}

\author{
Omar Rabee'a Mahdi (Corresponding author) \\ Graduate Business School, College of Graduate Studies, Tenaga Nasional University (UNITEN) \\ Jalan Ikram-Uniten, 43000 Kajang, Selangor, Malaysia \\ Tel: 60-14-734-3822Ｅ-mail: omaralmfraji80@yahoo.com \\ Mahmoud Khalid Almsafir \\ Graduate Business School, College of Graduate Studies, Tenaga Nasional University (UNITEN) \\ Jalan Ikram-Uniten, 43000 Kajang, Selangor, Malaysia \\ Tel: 60-19-260-9395 E-mail:mahmoud@uniten.edu.my
}

Received: January 10, 2012

doi:10.5539/ijbm.v7n7p94
Accepted: February 28, 2012

Published: April 1, 2012

\begin{abstract}
In this paper six sigma method for diagnosing the sustainable competitive advantages in organizations was proposed. The study used a survey strategy "self-administered questionnaire", to collect the primary data. The sample of the targeted population consists of 40 Doctors in public hygienic institutions in Iraq, with various functions and from different managerial levels. The analysis shows that six sigma methods in the organization's operations should be taken into consideration with necessary adaptation. The research proposes an approach that enables a systematic analysis of six sigma in diagnosing the sustainable competitive advantages in service organizations through the use of a survey strategy, called "self-administered questionnaire".
\end{abstract}

Keywords: Six Sigma methodology DMAIC, Sustainable Competitive advantage, Six Sigma’s belts

\section{Introduction}

"Six Sigma" method is one of the most recent quality improvement initiatives that has become more popular and accepted in many industries across the globe. Its use is increasingly wide spreading in many industries. Both service and manufacturing companies have adopted the methodology with many proponents of the approach claiming that it has developed beyond a quality control approach into a broader process improvement concept (AL-Mfraji \& Almsafir, 2012). Six sigma popularity has led to an increasing level of interest from the academic community while the basic concept has its origins in industry, with a substantial rise in the number of academic papers published in recent years (Nonthaleerak \& Hendry, 2006, 2008; Schroeder, Linderman, Liedtke, \& Choo, 2008). There are a numberof studies that focused on leadership commitment to the six sigma and discussed on the key issues such as; what would it bring to the organization and what are the business strategies, how it works and it's methodologies, the Definition-Measurement-Analysis-Improve-Controls (DMAIC) steps to be taken, what tools to be used and the deliverables, mathematical formulation of six sigma and what is the use of simulation with six sigma, new six sigma, benefits of six sigma, costs of six sigma and critical success factors and the future of six sigma (Mehrjerdi, 2011).

The organizations that have been implementing six sigma choose investment in the systematic discovery to the opportunities to improve quality at reduced costs, improve performance efficiency and effectiveness and customer service. Six sigma is one of the more recent quality management innovations which many organizations have adopted (Braunscheidel, Hamister, Suresh, \& Star, 2011). Six sigma initiatives are closely related to total quality management (TQM) initiatives (Arnheiter \& Maleyeff, 2005; Goeke \& Offodile, 2005; Thawani, 2004), considering that the quality management field, business processes and procedural thinking are central concepts that underpin six sigma (Antony, 2006; Bititci et al., 2011; Schroeder et al., 2008; Zu, Fredendall, \& Douglas, 2008). 
Many benefits of the successful implementation of six sigma to the business unit have been cited in literatures e.g. the customer satisfaction (Aboelmaged, 2011; S. Chen, Chen, \& Hsia, 2005; Desai, 2006; Kuei, \& Madu, 2003; M. Kumar, 2007; Rylander, 2006), as well as the adoption of six sigma methodologies impact on a firm's performance and competitive advantage (Braunscheidel et al., 2011). Six sigma offers research and experimentation methodologies that are have significantly impacted the project effectiveness. Recently, there have been published empirical researches on the application and implementation of six sigma methodologies, with some recent notable works (Braunscheidel et al., 2011; Gutiérrez, Lloréns-Montes, \& Sánchez, 2009; Linderman, Schroeder, Zaheer, \& Choo, 2003; McAdam \& Lafferty, 2004; Nonthaleerak \& Hendry, 2008; Schroeder et al., 2008; $\mathrm{Zu}$ et al., 2008). The program that features by its approach, which is associated with the customer and which also emphasizes on decision making is based on quantitative data as it addresses the problems in the five stages of DMAIC. It has helped the project leader in the implementation of project, improving a current process or improving performance quality of an existing product/service which initially does not meet customers' expectation. In addition, the gradual project methodology which the program displays is a structured tool consisting of statistical and non-statistical techniques, organizational structure and improvement of projects carried out by project leaders who can link with the problem. The team strained on project management and statistical methods of experimentation are referred to as Black Belts (BB) and Green Belts (GB). BB and GB are both supported by the so-called Champion or Sponsor, who are mostly workers with adequate experience. The Champion reviews theteam's progress to ensure that the BB and GB focus on the interests of the organization (Antony, 2006; de Mast, 2006). In health institutions, poor administrative awareness and absence of administrative systems in hospitals have reflected negatively on the performance of the health service in both public and private sector and this has indirect effect on customers' satisfaction. Therefore, the core idea for this study is to achievesustainable competitive advantage and to focus on the success and leader ship in improving processes and products to ensure quality of service in accordance with the principles of six sigma methodology (DMAIC), in the absence of integrated systematic approach for the preparation and development of the administrative organization of health institutions. The study will test the genuineness of this claim empirically, where the issues explored include the practitioners' difficulties and concerns when undertaking the six sigma projects through the methodology. Alternatively, it can only have the sincerity on theoretical basis, and this is what the current study intends to do. The research consists of three parts; first is the literature review, second is the review on the research methodology, followed by data analysis and discussion and thirdly, a list of conclusion and recommendations derived.

\section{Literature Review}

The following section provides a summary of the academic literature that is relevant to this study. It includes a section on six sigma from an academic perspective, Leadership of six sigma, six sigma's Belt and a section on Sustainable Competitive Advantage.

\subsection{Six Sigma}

Sigma $(\sigma)$ is a letter in the Greek alphabet that has become the statistical symbol and metric of process variation. Statisticianshave usedthis symbolto indicate thestandard deviation (Park, 2003). Standard deviation is a statistical way to describe how much variation exists in a set of data, a group of items, or a process. The term sigma is a measure indicating the deviation in the performance characteristic of a service from its mean performance (Antony, 2006). Six is the number of sigma measured in a process, when the variation around the target is such that only 3.4 outputs out of one million are defects under the assumption that the process average may drift over the long term by as much as 1.5 standard deviations. Park, (2003) defined six sigma as a new management strategy under leadership of top-level management to create quality innovation and total customer satisfaction. It is also a quality culture. It provides means of doing things right the first time and to work smarter by using data information. Sager \& Winkelman, (2001) defined six sigma as a methodology focused on improving processes. For years six sigma was viewed simply as a process improvement tool (like total quality management) to help companies to improve their manufacturing operations and reduce product defects. Antony \& Banuelas, (2002) noted that six sigma is a disciplined approach to define, measure, analyze, improve and control processes that result in variability and defect reduction. The six sigma of today speaks the language of management: bottom-line results. It institutionalizes a rigorous, disciplined, fact-based way to deliver more money to the bottom line through process improvement and process design projects selected by the top leadership and led by high potentials trained as Black Belts or Master Black Belts in six sigma that aims to create near-perfect processes, products, and services all aligned to delivering what the customer wants. Harry, (1998) defined six sigma to be "a strategic initiative to boost profitability, increase market share and improve customer satisfaction through statistical tools that can lead to break through quantum gains in quality" as quoted by (Park, 2003). 
Antony, (2006) added that the basic goal of a six sigma methodology is to reduce variation within the tolerance or specification limits of a service performance characteristic. In order to improve the quality of a typical service, it is imperative to measure or quantify variation and then develop potential strategies to reduce variation. Gilbert, (2003) described six sigma as "a way of doing business" and as a sweeping "culture change" effort to position a company for greater customer satisfaction, profitability, and competitiveness" through genuine focus on the customer, data and fact driven management, process focus, management, improvement proactive management boundary less collaboration and drive for perfection. Antony \& Fergusson, (2004) emphasized that six sigma is a business improvement strategy that seeks to find and eliminate causes of defects or mistakes in business processes by focusing on outputs that are of critical importance to customers. Camgoz-Akdag, (2004) defined six sigma as the basis for a "best in class" philosophy and a long term business strategy that measures quality improvement. Six sigma means less than four (3.4) defects or errors experienced for every 1 million transactions that is, only one out of every 250,000 parts produced would not fully meet all aspects of the customer's product specification. Simply put, "first time" six sigma performance is a commitment to perfection (Elliott, 2004). Six Sigma efforts target three main areas; (i) improving customer satisfaction, (ii) reducing cycle time and (iii) reducing defects (Pande \& Holpp, 2002). In addition, Park (2003) stated that it is possible to define three broad levels of objectives: management innovation, statistical measurement and process evaluation, and Strategic improvement by problem solving. Finally, Improvements in these areas usually represent dramatic cost saving to businesses, as well as opportunities to retain customers, capture new markets, and build a reputation for top performing products and services.

\subsection{Methodology of Six Sigma}

Six sigma is a project to solve problems. Each project has a problem in the design or operation and is looking for a solution. The successful strategy under the guidance of six sigma leadership is to find solutions and improve the basic production lines to achieve competitive advantage for the organization. Six sigma has no strategic implications until it is given some by top management (de Mast, 2006). Six sigma can provide leaders with the strategy, methods and tools to change their organization (Camgoz-Akdag, 2004). There are many authors such as (Camgoz-Akdag, 2004; Stauffer, 2003; Thawani, 2004) that agreed in their studies with these points. They pointed out that a key leadership skill has beenmissing from leadership development. Lee, Wong, \& Yeung (2011) pointed out in this regard that leadership ability plays a critical part in any quality improvement program, particularly the six sigma project that is always said to be a top-down quality revolution approach. For an organization having a strong and active top management to involve and to provide guidance in the quality improvement process, the six sigma program is more likely to be ready to achieve ultimate success for the project. This strategy paid executives toward the field of business, technology, manufacturing, quality, production and delivery system. Identifying the problem is a small amount compared to determining the causes leading to it. These reasons are often coated with inaccurate financial reports, and data is appropriate or cultural bias of the institution. There are two major improvement methodologies in applying the six sigma approach in different organizations. The first methodology, DMAIC, is used to improve already existing processes and can be divided into five phases; defining, measuring, analyzing, improving and controlling (Aboelmaged, 2011). Many studies have demonstrated successful cases of DMAIC application in a diversity of contexts such as healthcare (Dreachslin \& Lee, 2007), and manufacturing process (Li, Al-Refaie, \& Yang, 2008; Tong, Tsung, \& Yen, 2004), thermal power plants (Kaushik \& Khanduja, 2008), retailing,(M. Kumar, Antony, \& Cho, 2009) and financial services (S. Kumar, Wolfe, \& Wolfe, 2008). In contrast, the second methodology, DMADV, is used for new processes or when the existing processes are unable to achieve business objectives. This methodology can also be divided into five phases; defining, measuring, analyzing, designing and verifying (Bañuelas \& Antony, 2003). The focus will be onthe first methodology, DMAIC, as it is one of the methodsor approachesused inapplicationsof six sigma to implement the successful strategy to get six sigma quality in continuous improvement of procedures and processes in organizations (Schoonover, 2002; de Mast, 2006).

Phase 1. Defining - includes defining the scope and goals of the improvement project and appreciating boundaries of that project in terms of customer requirements and the process that delivers these requirements (Lee et al., 2011). This helps to communicate with customers, stockholders employees and all that is relevant. The purpose of this Phase is: (1) better understanding of the problem under study; (2) Identifying inputs and outputs and various controls of the processes; (3) determining the responsibilities, work stages, goals and key points (Milestones) for follow-up; (3) identifying of the equipment team; (4) understanding the benefits expected from the project (Project Merits).

Phase 2. Measuring- The purpose of this phase is to measuring the current system and its process or performance from input, output and process and calculating the sigma capability for short and longer term 
process capability (Lee et al., 2011). Also, it identifies the strengths and weaknesses and determines the gaps for improvement (Antony, 2006). This phase involves a valid measurement that is reliable to assist in the control of the goals that is previously defined in the first phase.

Phase 3. Analyzing-successful strategy at this stage provides certain statistical methods, as well as some tools that isolate critical information to explain the existing defects in products or services. At this stage, the practical problems turned into statistical problems. The objective from this phase is the analysis of the system or operations to define different methods to eliminate the gap between the current performances to the system or operations and the objective to be carried out. In addition, benchmarking the process outputs, products or services, against recognized benchmark standards of performance may also be carried out (Lee et al., 2011). The purpose of this phase is: (1) better and accurate identification for the project by collecting more data that reflect the real situation; (2) detection of truth sources to the variation through a better understanding of the causal relationships between variables; (3) reduce the number of variables that deal with them and the phase of improvement; (4) identify and manage high risk input; (5) at this stage, there is a search for the answer to two questions: Is the problem permanent or casual? Is it related to technology or the process itself?

Phase 4. Improving- involves generating the improvement solutions and solving problems to stop them from re-occurring so that the required financial and other performance goals are met (Antony, 2006; Lee et al., 2011). This successful strategy focuses on the diagnosis, testing and implementation of strategies or key variables that contribute to the problem. This phase covers a six sigma design from the beginning to the end and as well as the products and services to six sigma. The essential role at this stage is to try to bridge the gap between the current situation and the target situation of operations. The methods used in this step should be verified to make sure that the desired goal has been achieved completely and have recipe continuity. The purpose of this phase is to ensure the relationship between the variables, testing and application of fundamental solutions to the problem is in order, for effectiveness and especially flexibility.

Phase 5. Controlling - In this phase successful strategy ensures non-recurrence of errors and defects by monitoring processes continuously, and set the foundations to ensure the work by new standardize approach. The standardized approach will be documented in systems such as ISO 9000 and standards of performance will be established using techniques like SPC to continue the process of improvement in a way that holds the gains. The purpose of this phase is to ensure that what has been achieved will continue and sustained in the long term, as well as the documentation of all improvement efforts and new procedures to work. In addition, the cycle is repeated, if further performance short falls are identified.

\subsection{Six Sigma's Belts}

The term six sigma's belt was first introduced by the Motorola Corporation by one of its experts to describe employees who are trained and experienced in applying statistical techniques to business processes and procedures so that they can make major positive contributions to the bottom line. Black Belt are these employees who have extensive experience in the use of tools suitable to the area of business in which they are employed (Antony, 2006; Ingle \& Roe, 2001). Master Black belt in many organizations is a coach, observer and adviser for the rest of those who are black belt. He or she is a true expert in the analytical tools of six sigma with a scientific background in engineering or science or a degree in business administration. Green Belt is the person coach on the six sigma's skills and almost at the level of black belt but he/she works as a team member or leader of six sigma team partially. The role of the Green Belt is to ensure the application of service operations such as new concepts, tools and design for six sigma included in the daily activities of the company and for six sigma applications (Ingle \& Roe, 2001; Narasimhan, 2009). Champion/Sponsor is the process owner or manager-in-charge of the areas targeted for improvement. He or she is usually the chief executive that provides guidelines for project selection and gives full support to the Black Belt or projects and the teams working in the six sigma as the project progresses (Ingle \& Roe, 2001; Narasimhan, 2009). Implementation leader is usually a position for the Executive Vice President of the company. The role of this person is to organize all the efforts of six sigma to get a range of skills and experience (Thomsett, 2005).

\section{Sustainable Competitive Advantage}

With increasing competition, competitive advantage tends to have shorter life (Al-Alak, \& Najim, 2011). As the global competition becomes increasingly fierce, how to sustain competitive advantage or achieve sustainable competitive advantage starts obtaining more attention. Barney, (1991) noted that when an organization is implementing a value creating strategy not being simultaneously implemented by any current or potential rivals, it can be said that the organization has a competitive advantage. However, when other organizations are unable to copy the benefits of this strategy, then it confirm the organization has a sustainable competitive advantage. In 
2008, Barney distinguished between the two types of competitive advantage: temporary and sustainable competitive advantage. According to him, competitive advantage typically results in high profits, but these profits attract competition, and competition limits the duration of competitive advantage in most cases, therefore most competitive advantagesare temporary. On the other hand, some competitive advantages are sustainable if competitors are unable to imitate the source of advantage or if no one conceives a better offering. Furthermore, Bani-Hani \& AL-Hawary, (2009) refers to the sustainable competitive advantage as to create some barriers that make firm's performance imitation difficult. That is, since the competitive advantage is at the heart of firm's performance Porter, (1985), it should protect itself from being despoiled and assimilate new sources of technologies, skills and core competencies. Additionally, Halawi, Aronson, \& McCarthy (2005) pointed out that sustainable competitive advantage is no longer rooted in physical assets and capital, but in effective channeling of intellectual capital. Worthy to note, (Coyne, 1986) assumed the types of capability gaps as sources of sustainable competitive advantage, which a firm could possess over competitor, such as functional/business system gaps, position gaps, regulatory/legal gaps, and cultural or organization/managerial quality gaps. Day \& Wensley (1988) and Halawi, Aronson, \& McCarthy (2005) focused on the elements involved in competitive advantage. Specifically, they identified two categorical sources of competitive advantage: superior skills (which are the distinctive capabilities of personnel that set them apart from the personnel of competing firms); and superior resources (which are the more tangible requirements for advantage that enable a firm to exercise its capabilities). In the present environment, the personnel truly understand customers' needs and are able to foster business-intimate relationships with them, and then they most certainly qualify as a sustainable competitive advantage (Srivastava, Anderson, \& Ow, 1999).

Considering all those definitions, there are four points that can be extracted (Mahdi, Almsafir, \& Yao, 2011): First, the subjects of sustaining competitive advantages are resources and skills. Some researchers have elaborated on the specific skills and resources that can contribute to a sustainable competitive advantage. Barney, (1991) stated that not all firm resources hold the potential of sustainable competitive advantages; instead, they must possess four attributes: rareness, value, inability to be imitated and inability to be substituted. Secondly, the process of sustaining competitive advantages is to transform resources and skills into competencies or capabilities. (Prahalad, \& Hamel, (1990) suggested that firms should combine their resources and skills into core competencies, loosely defined as that which a firm does distinctively well in relation to competitors. (Bharadwaj \& Varadarajan, 1993) discussed the specific combinations of skills and resources that are unique to service industries.

Thirdly, the objective of sustaining competitive advantages is to be better than or different from competitors or to prevent imitation from competitors. Coplin, (2002) pointed out that to sustain a competitive advantage, a company's own resources and capabilities must therefore be difficult to imitate, not easily substituted by other resources or capabilities, incapable of being rapidly developed elsewhere and firmly attached to the company that deploys or uses them.

The fourth point is to stand in a strategic point of view, to review the sustaining competitive advantages as a dynamic process. Pearce \& Robinson, (1991) and Czinkota, Kotabe, \& Mercer, (2005) agreed that sustainable competitive advantage is a sustainable strategy that set the organization apart from competitors, such as, price strategy, strategy-structure fit, communication strategy or cooperation between functional areas (Ramasodi, 2007). The enterprises build competitive advantage as continuum in mutual connection and form continuous corrugated track (Wei, Jinfu, \& Jianfeng, 2010).

To sum up, the subjects of SCA are resources and skills. Resources also refer to what someone calls "physical resources" while skills are also referred to as intellectual resources. Both resources and skills can be regarded as the value capture part in the value chain viewpoint. The media of SCA is competency or capability. The vital issue is how to transform the subjects of SCA into the media, which is also interpreted as the value creation part in the value chain viewpoint. The objectives for SCA to be achieved can be in form of financial returns in the accounting viewpoint, capability gaps, and the value protection part in the value chain viewpoint or customer recognition from business operation field. Finally, the subject-media-objective process of SCA needs to be kept updated in order to adapt to the fast changing environment. It is what is mentioned in the literature for sustainable competitive advantage of the current study that has addressed the following dimensions:

\subsection{Operational Efficiency and Effectiveness (OEE)}

OEE is based on the view that, in the end, six sigma projects would be beneficial to the company that pays for them; benefits for the customer are instrumental rather than the ultimate objective. For this reason, product quality (and its components design and conformance quality) are a less obvious perspective than process quality 
(six sigma projects improve processes rather than products), which consists of effectiveness and efficiency. For a process, being effective means that it delivers the right things, that is, things that represent value. The direct benefit of six sigma projects consists of their power to improve OEE. The economic potential of effectiveness is derived from the fact that more effective processes deliver more value. The economic potential of process efficiency is derived from its impact on cost-structure. But cashing these economic potentials in the form of increased profitability is not straight forward. As a result, competing on OEE alone is, generally speaking, a poor substitute for a competitive strategy, and increasing OEE by implementing six sigma does not automatically increase profitability. It is important to emphasize that OEE is important nevertheless. Even companies with a good strategy must constantly strive to increase their OEE, because any strategic advantage will be outweighed if the gap in OEE becomes too large. Thus, six sigma projects help avoid competitive disadvantage (Hayes \& Pisano, 1994; Porter, 1998a; de Mast, 2006). In fact it is possible to use six sigma to gain strategic benefits, if all a company does is invest in six sigma training and conduct BB and GB projects. Six sigma brings with it capabilities and skills that management can use to build competencies that cannot so easily be bought on the market or copied by competitors. These competencies open strategic options which, when properly fit into a company's competitive strategy, may result in sustainable advantages (Hayes \& Pisano, 1994; de Mast, 2006). Six sigma achieves a band of the strategic choices through triple Porter's three generic approaches for competitive strategy (Porter, 1998b): (1) overall cost leadership; (2) product differentiation; and (3) focus. Through this approach, it is noted that six sigma projects drive a strategy of cost-leadership by increasing efficiency, drive a strategy product differentiation by effectiveness.

\subsection{Knowledge making (KM)}

The meaning of the word "knowledge" is subject to a number of different interpretations. Yeh, (2011) deals with the knowledge concept as a force, in this direction pointed that knowledge powers the capability of professionals to be at their best, and to deliver value service to customers. Other writings have focused on the concept of knowledge to refer to it as intellectual capital and value-added, which if discovered and invested by the organization, it can be valuable and achieve competitive advantage (Al-Zayyat, Al-Khaldi, Tadros, \& Al-Edwan, 2009; Endres, Chowdhury, \& Alam, 2007; Mahdi et al., 2011; Othman, Yao, Mahdi, \& Jing, 2011; Seidler-de Alwis \& Hartmann, 2008).

While other definitions indicated that knowledge is information that has been processed in some meaningful ways merged with practice, perspective, expression and interpretation (Yao, Othman, Aballama, \& Mahdi, 2011). It presents characterized approaches as well as dynamic, strategic and politicalplans and subject to change on which decision is based on, from the pioneers of this trend (Laihonen, 2006; Sunassee \& Sewry, 2002; Williams, 2006). Knowledge as the Source of SCA and success of organization in investigating the sustainable competitive advantage do not depend primarily on the size of the budget or the products supporting technologies. It really depends on employee's attitudes, core competencies and skills (Al-Rfou, 2009; Thawani, 2004). Memon \& Mangi, (2009) agreed that the strategic human resources management or the human capital is a mean of gaining competitive advantage through one of the most important asset: its people as its essential wealth, success and competitive advantage of the organization. Porter, (1985) assumptions to implement any one, or a combination of the four possible generic competitive advantage options: cost leadership, focused cost leadership, differentiation and focused differentiation, an organization would possibly need the following types of knowledge: (1) strategic knowledge to include knowledge of market environment, customer requests, customer and rivals behavior; and (2) operational knowledge to achieve managerial and operational processes associated with logistics such as procurement of raw materials and distribution of goods, and production, etc, to sustain competitive advantage, in other words, to utilize the knowledge of people to contribute to the organization (Buckman \& NetLibrary, 2004; Sheikh, 2008).

This contribution to achieve sustainable competitive advantage to the organization by knowledge making could be brought about by six sigma, because six sigma is power to facilitate people at all levels of an organization to learn how their processes work and to put this new knowledge to effective use which is the core capability.

\subsection{Cost of Poor Quality (COPQ)}

Cost of Poor Quality (COPQ) is the monetary loss of products and processes that are not achieving their quality objectives (Gryna \& Juran, 2001). Six sigma is classed among initiatives for quality improvement and total quality management. The benefits of quality improvement initiatives are argued from their potential to: (1) increase customer satisfaction by improving product quality; (2) Reduce production costs by lowering costs associated with poor quality (de Mast, 2006). COPQ is traditionally subdivided into three categories called PAF as prevention costs, appraisal costs and failure costs. COPQ and the PAF components are used in the literature to 
establish a relationship between conformance levels and production costs. Thefailure costs refer to the difference between the real cost of producing the good or service and the costs in the absence of any failures, and these costs are the highest cost that was formed to achieve the quality when a company has reached $70-90 \%$ of the cost ofoverall quality. The failure costs can be classified into two types, namely:

i. Internal failure costs: these costs are discovered before they are sent to the consumer.

ii. External failure costs: is done through the receipt of the consumer of the product but quality are few.

Freiesleben, (2006) suggested that successful application of six sigma quality is positively correlated with better financial performance and profit generation. In the manufacturing context, six sigma has a positive impact on productivity and profitability as a result of reduction in process variability, inventory, maintenance time, and cost of poor quality. Service organizations adopting six sigma methodology will have improved service delivery as a result of accurate allocation of resources and reduced defects and variability in service processes (Antony, Kumar, \& Madu, 2005; Kwak \& Anbari, 2006).

\section{Methodology}

After the field survey of a sample of health institutions in Iraq, it has been identified that the problem they are experiencing are as follow: (1) high costandlow qualityof health services; (2) deterioration of the relationship between the service providers and the beneficiaries; (3) high cost of modern technology in the diagnosis and treatment and; (4) unavailability of new directions for the health strategy. The study was conducted using a procedural scheme as showed in Figure (1), where it demonstrates the systematic steps to the impact of sigmastrategies in order to achieve sustainable competitive advantage. The intellectual foundation which emerges in this process was derived from the ideas presented in the literature (Antony, 2006; Antony \& Banuelas, 2002; Dreachslin \& Lee, 2007; Harry, Michaels, Libretto, Bruce, \& Productions, 1997; Hayes \& Pisano, 1994; Kaushik \& Khanduja, 2008; M. Kumar \& Antony, 2009; S. Kumar et al., 2008; Li et al., 2008; Park, 2003; Porter, 1998a; Tong et al., 2004; de Mast, 2006).

\section{Insert Figure 1 here}

The scheme has been established based on hypotheses built on the basis of the nature of relations between the variables of the study and trends of influence. The achievement of its objectives as stated in the problem of the study. In line with the view suggested in the literature, thus the study hypothesized:

\section{H1: there is significant correlation between Six Sigma and SCA.}

H1a: there is significant correlation between Six Sigma and Operational Efficiency and effectiveness (OEE).

H1b: There is significant correlation between Six Sigma and Knowledge Making (KM).

H1c: there is significant correlation between Six Sigma and Cost of Poor Quality (COPQ).

\section{H2: there is significant impact by Six Sigma on SCA.}

H2a: there is significant impact by Six Sigma on Operational Efficiency and Effectiveness (OEE).

$\mathrm{H} 2 \mathrm{~b}$ : there is significant impact by Six Sigma on Knowledge Making (KM).

H2c: there is significant impact by Six Sigma on Cost of Poor Quality (COPQ).

In this study there are three kinds of statistical analyses that were carried out on the data obtained from the respondent. First, descriptive analysis was used to analyze the background of the respondent; secondly, correlation analysis was used to analyze the relationship between six sigma and Sustainable Competitive Advantage (SCA); and thirdly, regression analysis for investigation of the impact of six sigma on Sustainable Competitive Advantage (SCA).

\subsection{Questionnaire Design}

The data for this study were collected via a questionnaire survey. Most of the measurement items in the questionnaire were based on previous studies. Content validity was ensured through an extensive literature review of published material in academic and practitioner journals, and by discussion with several experts and scholars in this field. The questionnaire was comprised of four parts: health institutions profiles of respondents (part I); procedural definitions to the study variables (part II); Six sigma methodology DMAIC (part III); and dimensions of sustainable competitive advantaged (part IV). The present study adopted an existing five-point Likert scale, where 1 represented "strongly disagree" and 5 represented "strongly agree." All items in the questionnaire adopted the same five-point Likert scale. 


\subsection{Data Collection}

The sample for this study was chosen based on random sample of (40) doctors in health institution. The survey was distributed directly to the 40 doctors, and a total of 30 questionnaires were returned or ( 90 percent). 10 of the 40 returned questionnaires were discarded because of incomplete information. There were 30 usable responses in total, for an overall response rate of $75 \%$. Research analytical methods included exploratory factor analysis, reliability and validity. The analyses made use of SPSS (version 18) program for Windows to carry out the dissipative statistical analysis.

\section{Findings}

\subsection{Descriptive Analysis}

For the responding descriptive analysis there were 26 ( 87 percent) male respondents, while 4 (13 percent) of the respondent are female. As for the scientific qualified 12 (40 percent) respondent attained $\mathrm{PhD}$ level, 4 (13 percent) master level and 14 (47 percent) bachelor levels.

\subsection{Reliability Analysis}

Reliability analysis was carried out for each variable: six sigma and the Sustainable Competitive Advantage (SCA). The results score ranged from .605 to .911 as show in table 1 . The results are normally within acceptable limit for social studies.

\section{Insert Table 1 here}

\subsection{Normality Distribution Analysis}

Table 2 shows the descriptive statistics for the sample of the study showing the mean, standard deviation, maximum, minimum, skewness and kurtosis. The descriptive statistics represent all the independent variables which are Definition-Measurement-Analysis-Improve-Controls (DMAIC) used to examine the impact of six sigma on the dependent variable Operational Efficiency and Effectiveness (OEE), Knowledge Making (KM) and Cost of Poor Quality (COPQ) used to examine the Sustainable Competitive Advantage (SCA).

The normality of the data was assessed using the skewness and kurtosis statistics derived from the descriptive statistics which should have a range of -1 and +1 . If the range belongs to the above range, then the distribution is normally distributed and therefore there is a need for transforming the data to normal distribution in order to perform the necessity statistical tests.

\section{Insert Table 2 here}

\subsection{Correlation Analysis}

This part of the study is to seek the correlation between the variables dimensions, through an appropriate statistical analysis. In here, Spearman's Rank Correlation Coefficient has been used to determine the relationship between study variables. In addition, it identifies significant opposites the potential valueof the error from first type, and it is the amount at which the probability of the uncertainty valueis at significance $(0.05)$ and $(0.01)$ to determine the moral differences between the study variables.

\subsubsection{Testing hypothesis}

\section{H1: there is significant correlation between Six Sigma and SCA.}

\section{H1a: there is significant correlation between Six Sigma and (OEE).}

Statistical results the correlation between six sigma methodology and dimensions diagnosis of sustainable competitive advantage are shown in table 3. Spearman's Rank Correlation Coefficient value on the relationship between six sigma methodology and Operational Efficiency and Effectiveness (OEE) was $0.815^{* *}$ at a significance smaller than 0.01 . It is a significant positive correlation. This means six sigma methodology have strong significant correlation with efficiency and effectiveness (OEE) and the opposite is true. This in turn supports the sub-hypothesis mentioned above.

\section{H1b: There is significant correlation between Six Sigma and (KM).}

Table 3 shows the statistical results of the correlation between six sigma methodology and dimensions diagnosis of sustainable competitive advantage. Spearman's Rank Correlation Coefficient value about the relationship between six sigma methodology and knowledge making $(\mathrm{KM})$ was $0.930^{* *}$, at significance smaller than 0.01 .It is significant positive correlation. This means six sigma methodology have strong significant correlation with knowledge making (KM) and the opposite is true. This in turnsupports the sub-hypothesis mentioned above.

\section{H1c: there is significant correlation between Six Sigma and (COPQ).}


Table 3 shows the statistical results of the correlation between six sigma methodology and dimensions diagnosis of sustainable competitive advantage Spearman's Rank Correlation Coefficient value on the relationship between six sigma methodology and Cost of Poor Quality (COPQ) was $0.667^{* *}$, at significance smaller than 0.01 . It is significant positive correlation. This means that six sigma methodology has a strong significant correlation with Cost of Poor Quality (COPQ) and the opposite is true. This in-turn supports the sub-hypothesis mentioned above.

\section{Insert Table 3 here}

Verification validity of the content of sub-hypotheses (H1a), (H1b) and (H1c) for the first main hypothesis through the Spearman's Rank Correlation Coefficient value between six sigma methodology was $0.878^{* *}$ at significance smaller than 0.01 . It is significant positive correlation. This shows that six sigma methodology has strong significant correlation relations with dimensions diagnosis of sustainable competitive advantage. This in turn verifies the validity of the first main hypothesis.

\subsection{Regression}

The analytical study has been used of simple linear regression method to measure the impact between the independent variables and the dependent variable. After measuring the impact, it is proven by the adjusted coefficient of determination $\mathrm{R}^{2}$, which shows the percentage explained by the independent variable changes in the dependent variable. Thus, the value of $R^{2}$ is located between 0 and 1 , means $1>R^{2}>0$, whenever the value of $\mathrm{R}^{2}$ become big, the interpretation strength of the regression equation become big. Fitness test $(\mathrm{F})$ was made to analyze variance for measuring the significance model of simple linear regression to measure the degree of appreciates (Fitness) as dependent model while the value of indexed (F) is 2.39. In addition, adoption of the statistical indicator supported note that the value of $(\mathrm{F})$ spread sheet is, as well as the adoption of the statistical indict or Beta Coefficient (B) or called by the amount of tendency regression model to determine the amount of change (impact) in the dependent variableunit when the value of the independent variable was changed by one unit. If the tendency significant degree is less than 0.05 , means $\mathrm{P}<0.05$, that is evidence of the impact of the independent variable in the dependent variable and the opposite is true. Therefore, this section includes the impact between the variables of the study according to the study hypotheses, as follows Table 4 .

\subsubsection{Testing hypothesis}

Insert Table 4 here

\section{H2: there is significant impact by Six Sigma on SCA.}

\section{H2a: there is significant impact by Six Sigma on (OEE).}

Table (4) showed the relations between six sigma methodology and Operational Efficiency and Effectiveness (OEE) were acceptable. As indicated in the (F) test, the calculated (F) value 118.815 is the largest of the indexed value (F) at significance less than 0.01 . As the result of the value of the adjusted coefficient (interpretation) $\mathrm{R}^{2}$ is 0.802 . It means that the six sigma methodology explained and interpreted $80.2 \%$ from the gained changes in the respondent variable (dependent) of the efficiency and effectiveness (OEE). In addition, it has been pointed from the value of the Beta coefficient (B) that the six sigma methodology as an explanatory variable (independent) significant effect on the efficiency and effectiveness (OEE) as respondent variable (dependent) was 0.900 at significance less than 0.01 . This refers to the change of one unit in the six sigma methodology followed by an increase of 0.900 in the efficiency and effectiveness (OEE). This achieves sub-hypothesis mentioned in the above.

\section{H2b: there is significant impact by Six Sigma on (KM).}

Statistical results in table (4) illustrate that relations between six sigma methodology and knowledge making $(\mathrm{KM})$ were acceptable. As indicated in the test $(\mathrm{F})$ has the value $(\mathrm{F})$ calculated 146.718 is the largest of the indexed value (F) at significance less than 0.01 . As the result, value of the adjusted coefficient (interpretation) $\mathrm{R}^{2}$ is 0.834 . This means that the six sigma methodology explain and interpret $83.4 \%$ from the gained changes in the respondent variable (dependent) to the knowledge making (KM). In addition, it also has been pointed from the value of the Beta coefficient (B) that the six sigma methodology as an explanatory variable (independent) has significant effect on the knowledge making (KM) as respondent variable (dependent) was 0.916 at significance less than 0.01. In other word, the change of one unit in the six sigma methodology followed is by an increase of 0.916 in the knowledge making (KM). This achieves sub-hypothesis mentioned in the above.

\section{H2c: there is significant impact by Six Sigma on (COPQ).}

Statistical results demonstrate in table (4) that relations between six sigma methodology and Cost of Poor 
Quality (COPQ) were acceptable. As indicated in the test, (F) has the calculated value of 58.607; it is the largest of the indexed value $(\mathrm{F})$ indexed at significance less than 0.01 . As the result, value of the adjusted coefficient (interpretation) $\mathrm{R}^{2}$ is 0.665 . This means that the six sigmamethodology explain and interpret $66.5 \%$ from the gained changes in the respondent variable (dependent) of the Cost of Poor Quality (COPQ). In addition, has been pointed from the value of the Beta coefficient (B) that the six sigma methodology as an explanatory variable (independent) significant effect on the Cost of Poor Quality (COPQ) as respondent variable (dependent) was 0.823 at significance less than 0.01 . This means that the change of one unit in the six sigma methodology is followed by an increase of 0.823 in the Cost of Poor Quality (COPQ). This achieves sub-hypothesis mentioned in the above.

After verification from validity of the content of sub-hypotheses (H2a), H2b and $\mathbf{H 2 c}$ verify the authenticity of the content of the second main hypothesis. The results of test value (F) achieve calculated value is 42.475 at significance less than 0.01 . Which indicate that relations mode between six sigma methodology and sustainable competitive advantaged was acceptable. The adjusted coefficient (interpretation) $\mathrm{R}^{2}$ achieve value is 0.589 , in the other word, six sigma methodology explain and interpret 58\% from the gained changes in the respondent variable (dependent) of the sustainable competitive advantaged. As has been pointed from the value of the Beta coefficient (B) there is significant impact to the six sigma methodology as an explanatory variable (independent) in the sustainable competitive advantaged as respondent variable (dependent) was 0.776 at significance less than 0.01 . This in-turn verifies validity the second main hypothesis.

\section{Conclusions}

The term six sigma and consequently the six sigma methodology are characterized as modernity. Research is still in early stages at all level of the organizations under consideration. After the field survey of a sample of health institutions, it has been shown that there are a set of trends that health institutions are keeping and these are high cost and low quality of health services, deterioration of the relationship between the service providers and the beneficiaries, high cost of modern technology in the diagnosis and treatment and unavailability of new directions for the health strategy. The researchers determined the nature of the six sigma differently where some of them considered process, and some of them promise a strategy, mechanism, technique or method to handle a specific problem. This variation is a source from scientific richest and high interest obtained by this term. Moreover, there is limited knowledge of doctors' research samples in this term on both conceptual and practical dimensions. Furthermore, the levels of the dimensions of the application of six sigma methodology in the health institutions under consideration are somewhat close and its mean over the hypothetical mean slightly differs. There are significant correlation relationships between dimensions diagnosis of sustainable competitive advantage, which also reflects the harmony, homogeneity and integration of these dimensions. In addition, there is a great six sigma methodology in the diagnosis dimensions of sustainable competitive advantage, efficiency and effectiveness (OEE), making knowledge (KM), and Cost of Poor Quality (COPQ).

\section{References}

Aboelmaged, M. G. (2011). Reconstructing Six Sigma barriers in manufacturing and service organizations: The effects of organizational parameters. International Journal of Quality \& Reliability Management, 28(5), 519-541. http://dx.doi.org/10.1108/02656711111132562

Al-Alak, B.A.M., \& Najim, A. N. (2011). Marketing Intangibles-Based Competitive Advantage: A Paradigm Shift beyond Traditional Management. Journal of Advanced Social Research, 1(2), 169-176.

AL-Mfraji, O. R., \& Almsafir, M. K. (2012). Sustainable Competitive Advantage Using Six Sigma Methodology: Review. Journal of Modern Marketing Research, 1(1), 10-26.

Al-Rfou, A. (2009). Achieve Competitive Advantage through Job Motivation. J Soc Sci, 20(2), 105-107.

Al-Zayyat, A. N., Al-Khaldi, F., Tadros, I., \& Al-Edwan, G. (2009). The Effect of Knowledge Management Processes on project Management an Empirical Study on Information Technology Industry in Jordan. IBIMA Bus. Rev, 3, 47-52.

Antony, J. (2006). Six sigma for service processes. Business Process Management Journal, 12(2), 234-248. http://dx.doi.org/ 10.1108/14637150610657558

Antony, J., \& Banuelas, R. (2002). Key ingredients for the effective implementation of Six Sigma program. Measuring Business Excellence, 6(4), 20-27. MCB UP Ltd. http://dx.doi.org/10.1108/13683040210451679

Antony, J., \& Fergusson, C. (2004). Six Sigma in the software industry: results from a pilot study. Managerial Auditing Journal, 19(8), 1025-1032. http://dx.doi.org/10.1108/02686900410557926 
Antony, J., Kumar, M., \& Madu, C. N. (2005). Six sigma in small-and medium-sized UK manufacturing enterprises: Some empirical observations. International Journal of Quality \& Reliability Management, 22(8), 860-874. http://dx.doi.org/10.1108/02656710510617265

Arnheiter, E. D., \& Maleyeff, J. (2005). The integration of lean management and Six Sigma. The TQM magazine, 17(1), 5-18. http://dx.doi.org/ 10.1108/09544780510573020

Bani-Hani, J. S., \& AL-Hawary, F. (2009). The impact of core competencies on competitive advantage: Strategic challenge. International Bulletin of Business Administration, 6, 93-104.

Bañuelas, R., \& Antony, J. (2003). Going from six sigma to design for six sigma: an exploratory study using analytic hierarchy process. The TQM Magazine, 15(5), 334-344. MCB UP Ltd.

Barney, J. (1991). Firm resources and sustained competitive advantage. Journal of management, 17(1), 99-120. Sage Publications. http://dx.doi.org/10.1108/09544780310487730

Bharadwaj, S. G., \& Varadarajan, P. R. (1993). Sustainable competitive advantage in service industries: a conceptual model and research propositions. The Journal of Marketing, 57, 83-99. JSTOR.

Bititci, U. S., Ackermann, F., Ates, A., Davies, J., Garengo, P., Gibb, S., \& MacBryde, J. et al. (2011). Managerial processes: business process that sustain performance. International Journal of Operations \& Production Management, 31(8), 851-891. http://dx.doi.org/10.1108/01443571111153076

Braunscheidel, M. J., Hamister, J. W., Suresh, N. C., \& Star, H. (2011). An institutional theory perspective on Six Sigma adoption. International Journal of Operations \& Production Management, 31(4), 423-451. http://dx.doi.org/10.1108/01443571111119542

Buckman, R. H., \& NetLibrary, I. (2004). Building a knowledge-driven organization. McGraw-Hill.

Camgoz-Akdag, H. (2004). The impact of TQM applications to the competitiveness of Companies. $\mathrm{PhD}$ thesis. University Brunel, London. http://dx.doi.org/10.1108/14635770710740387

Chen, S., Chen, K., \& Hsia, T. (2005). Promoting customer satisfactions by applying six sigma example of automobile industry process. Quality Management Journal, 12(4), 21-33.

Coplin, L. C. H. (2002). Competitive Advantages and the SMEs: The Role of Distinctive Competences as Determinants of Success, Are There Differences across Gender, Sector, And Size? Ph.D. Thesis. University Autonoma De Barcelona, Barcelona, Spain.

Coyne, K. (1986). Sustainable competitive advantage--What it is, what it isn't. Business horizons, 10(1), 54-61. http://dx.doi.org/10.1016/0007-6813(86)90087-X

Czinkota, M. R., Kotabe, M., \& Mercer, D. (2005). Marketing Management: Text and Cases. USA: Blackwell Business.

Day, G. S., \& Wensley, R. (1988). Assessing advantage: a framework for diagnosing competitive superiority. The Journal of Marketing, 52, 1-20. JSTOR. http://dx.doi.org/10.1108/02656711111132562

de Mast, J. (2006). Six Sigma and competitive advantage. Total Quality Management and Business Excellence, $17(04), 455-464$.

Desai, D. A. (2006). Applying Six Sigma and DMAIC to diversity initiatives. International Journal of Six Sigma and Competitive Advantage, 2(1), 23-47.

Dreachslin, J., \& Lee, P. D. (2007). Applying Six Sigma and DMAIC to diversity initiatives. Journal of healthcare management/American College of Healthcare Executives, 52(6), 361.

Elliott, G. (2004). The journey to steps to six sigma. Handbook of Business Strategy, 5(1), 201-205.

Endres, M. L., Endres, S. P., Chowdhury, S. K., \& Alam, I. (2007). Tacit knowledge sharing, self-efficacy theory, and application to the Open Source community. Journal of knowledge management, 11(3), 92-103. http://dx.doi.org/10.1108/13673270710752135

Freiesleben, J. (2006). Communicating six sigma's benefits to top management. Measuring Business Excellence, 10(2), 19-27. Emerald Group Publishing Limited. http://dx.doi.org/10.1108/13683040610668675

Gilbert, E. (2003). Integrating Accelerated Problem Solving into Six Sigma Process Improvement Methodology. Thesis of north Crolina State University, USA.

Goeke, R. J., \& Offodile, O. F. (2005). Forecasting Management Philosophy of Life Cycles: A Comparative Study of Six Sigma and TQM. Quality management journal, 12(2), 34-46. 
Gryna, F., \& Juran, J. M. (2001). Quality planning and analysis: from product development through use (4th ed.). McGraw-Hill Science/Engineering/Math.

Gutiérrez, L. J. G., Lloréns-Montes, F., \& Sánchez, Ó. F. B. (2009). Six sigma: from a goal-theoretic perspective to shared-vision development. International Journal of Operations \& Production Management, 29(2), 151-169. http://dx.doi.org/10.1108/01443570910932039

Halawi, L., Aronson, J., and McCarthy, R. (2005). Resource-based view of knowledge management for competitive advantage. Electronic Journal of Knowledge Management, 3(2), 75-86.

Harry, M. (1998). Six Sigma: a breakthrough strategy for profitability. Quality progress, 31(5), 60-64.

Harry, M. J., Michaels, J., Libretto, J., Bruce, G., \& Productions, N. N. (1997). The Vision of Six Sigma: A roadmap for breakthrough (5th ed.). Tri star publ.

Hayes, R.H., and Pisano, G. P. (1994). Beyond world-class: the new manufacturing strategy. Harvard Business Review, 72(1), 77-86. Macmillan Business London, Great Britain.

Ingle, S. \& Roe, W. (2001). Six sigma Black Belt implementation. The TQM Magazine. The TQM Magazine, 13(4), 273-280. http://dx.doi.org/10.1108/09544780110391666

Kaushik, P., \& Khanduja, D. (2008). DM make up water reduction in thermal power plants using Six Sigma DMAIC methodology. Journal of Scientific and Industrial, 67(1), 36-42.

Kuei, C-H., and Madu, C. (2003). Customer-centric six sigma quality and reliability management. International Journal of Quality \& Reliability Management, 20(8), 954-964. http://dx.doi.org/10.1108/02656710310493661

Kumar, M. (2007). Critical success factors and hurdles to Six Sigma implementation: the case of a UK manufacturing SME. International Journal of Six Sigma and Competitive, 3(4), 333-351. http://dx.doi.org/10.1504/IJSSCA.2007.017176

Kumar, M., \& Antony, J. (2009). Project selection and its impact on the successful deployment of Six Sigma. Business Process Management, 15(5), 669-86. http://dx.doi.org/10.1504/IJSSCA.2007.017176

Kumar, M., Antony, J., \& Cho, B. R. (2009). Project selection and its impact on the successful deployment of Six Sigma. Business Process Management Journal, 15(5), 669-686.

Kumar, S., Wolfe, A., \& Wolfe, K. A. (2008). Using Six Sigma DMAIC to improve credit initiation process in a financial services operation. International Journal of Productivity and Performance Management, 57(8), 659-676. http://dx.doi.org/10.1108/17410400810916071

Kwak, Y.H., \& Anbari, F. T. (2006). Benefits, obstacles, and future of six sigma approach. Technovation, 26, 708-715. http://dx.doi.org/10.1016/j.technovation.2004.10.003

Laihonen, H. (2006). Knowledge flows in self-organizing processes. Journal of knowledge management, 10(4), 127-135. http://dx.doi.org/10.1108/13673270610679417

Lee, T., Wong, W., \& Yeung, K. (2011). Developing a readiness self-assessment model (RSM) for Six Sigma for China enterprises. International Journal of Quality \& Reliability Management, 28(2), 169-194. http://dx.doi.org/10.1108/02656711111101746

Li, M. H. C., Al-Refaie, A., \& Yang, C. Y. (2008). DMAIC approach to improve the capability of SMT solder printing process. Electronics Packaging Manufacturing, IEEE Transactions on, 31(2), 126-133. IEEE. http://dx.doi.org/10.1109/TEPM.2008.919342

Linderman, K., Schroeder, R. G., Zaheer, S., \& Choo, A. S. (2003). Six Sigma: a goal-theoretic perspective. Journal of Operations Management, 21(2), 193-203. http://dx.doi.org/10.1016/S0272-6963(02)00087-6

Mahdi, O. R., Almsafir, M. K., \& Yao, L. (2011). The role of knowledge and knowledge management in sustaining competitive advantage within organizations: A review. Journal of Business, 5(23), 9912-9931.

McAdam, R., \& Lafferty, B. (2004). A multilevel case study critique of six sigma: statistical control or strategic change? International Journal of Operations \& Production Management, 24(5), 530-549. http://dx.doi.org/10.1108/01443570410532579

Mehrjerdi, Y. Z. (2011). Six-Sigma: methodology, tools and its future. Assembly Automation, 31(1), 79-88. Emerald Group Publishing Limited. http://dx.doi.org/10.1108/01445151111104209

Memon, M. A., \& Mangi, R. A. (2009). Human Capital a Source of Competitive Advantage, Ideas for Strategic Leadership. Austr. J. Basic Appl. Sci. AJBAS, 3(4), 4182-4189. 
Narasimhan, K. (2009). Design for Six Sigma for Green Belts and Champions: Applications for Service Operations. Managing Service Quality, 19(5), 628 - 629.

Nonthaleerak, P., \& Hendry, L. (2006). Six Sigma: literature review and key future research areas. International Journal of Six Sigma and Competitive Advantage, 2(2), 105-161. http://dx.doi.org/10.1108/01443570810856198

Nonthaleerak, P., \& Hendry, L. (2008). Exploring the six sigma phenomenon using multiple case study evidence. International Journal of Operations \& Production Management, 28(3), 279-303.

Othman, A., Yao, L., Mahdi, O. R., \& Jing, W. (2011). A Novel Statistical Model Assessing The Self Performance Of Knowledge Management Within Smes In China. Procedia Engineering, 15(2005), 1758-1763. http://dx.doi.org/10.1016/j.proeng.2011.08.328

Pande, P. S., \& Holpp, L. (2002). What is six sigma? McGraw-Hill Professional.

Park, S. H. (2003). Six Sigma for quality and productivity promotion. Asian Productivity Organization.

Pearce, J. A., \& Robinson, R. B. (1991). Formulation, implementation, and control of competitive strategy (9th ed.). New York: Irwin.

Porter, M. E. (1985). Competitive advantage: creating and sustaining superior performance: with a new introduction. Free Pr.

Porter, M. E. (1998a). Competitive strategy: Techniques for analyzing industries and competitors. New York: The Free Press.

Porter, M. E. (1998b). Competitive advantage: creating and sustaining superior performance: with a new introduction. New York: Free Pr.

Prahalad, C. (2006). The core competence of the corporation. Harvard Business Review, 79-91.

Ramasodi, S. E. (2007). The Marketing-Logistics Interface: A Way to Sustainable Competitive Advantage in the Passenger Car Industry in South Africa. Master's Thesis. University of Johannesburg.

Rylander, D. (2006). Improving the odds: combining six sigma and online market research for better customer service. SAM Advanced Management, 71(1), 13.

Sager, T., \& Winkelman, S. L. (2001). Six sigma: Positioning for competitive advantage. ACCA Docket, 19(1), $18-27$.

Schoonover, S. C. (2002). Six Sigma Leadership: The Key to Sustaining Contemporary Quality Programs. Schoonover Associates. Inc.

Schroeder, R. G., Linderman, K., Liedtke, C., \& Choo, A. S. (2008). Six Sigma: Definition and underlying theory. Journal of Operations Management, 26(4), 536-554. http://dx.doi.org/10.1016/j.jom.2007.06.007

Seidler-de Alwis, R., \& Hartmann, E. (2008). The use of tacit knowledge within innovative companies: knowledge management in innovative enterprises. Journal of knowledge management, 12(1), 133-147. http://dx.doi.org/10.1108/13673270810852449

Sheikh, S. A. (2008). Use of new knowledge and knowledge management to gain competitive advantage. Communications of the IBIMA, 1(4), 34-41.

Srivastava, V., Anderson, O. D., \& Ow, D. W. (1999). Single-copy transgenic wheat generated through the resolution of complex integration patterns. Proceedings of the National Academy of Sciences, 96(20), 11117-11121.

Stauffer, D. (2003). Is your benchmarking doing the right work. Harvard Management Update, 8(8).

Sunassee, N. N., \& Sewry, D. A. (2002). A theoretical framework for knowledge management implementation. Proceedings of the 2002 annual research conference of the South African institute of computer scientists and information technologists on Enablement through technology (Vol. 7, pp. 235-245). South African Institute for Computer Scientists and Information Technologists.

Thawani, S. (2004). Six sigma - strategy for organizational excellence. Total Quality Management \& Business Excellence, 15(5-6), 655-664.

Thomsett, M. C. (2005). Getting started in six sigma. John Wiley \& Sons Inc.

Tong, J., Tsung, F., \& Yen, B. (2004). A DMAIC approach to printed circuit board quality improvement. The International Journal of Advanced Manufacturing Technology, 23(7), 523-531. http://dx.doi.org/10.1007/s00170-003-1721-z 
Wei, X., Jinfu, Y., \& Jianfeng, C. (2010). The study on the influence of IT capabilities to the Sustainable Competitive Advantage. Industrial Mechatronics and Automation (ICIMA), 2010 2nd International Conference on (Vol. 2, pp. 685-688).

Williams, R. (2006). Narratives of knowledge and intelligence beyond the tacit and explicit. Journal of Knowledge Management, 10(4), 35-42. http://dx.doi.org/10.1108/13673270610679381

Yao, L., Othman, A. B., Aballama, A. N., \& Mahdi, O. R. (2011). E-management development and deployment strategy for future organization. Journal of Business, 5(16), 6657-6667.

Yeh, Y. (2011). The Implementation of Knowledge Management System in Taiwan's Higher Education. Journal of College Teaching \&amp; Learning (TLC), 2(9), 35-42.

$\mathrm{Zu}, \mathrm{X}$., Fredendall, L., \& Douglas, T. J. (2008). The evolving theory of quality management: the role of Six Sigma. Journal of Operations Management, 26(5), 630-650. http://dx.doi.org/10.1016/j.jom.2008.02.001

Table 1. Reliability Analysis

\begin{tabular}{|c|l|c|c|}
\hline \multicolumn{2}{|c|}{ Variables Factors } & Cronbach's Alpha & Number Of Items \\
\hline \multirow{2}{*}{ I.V } & six sigma & .898 & 27 \\
\hline \multirow{3}{*}{ D.V } & Efficiency and Effectiveness (OEE) & .828 & 14 \\
\cline { 2 - 4 } & Knowledge Making (KM) & .911 & 6 \\
\cline { 2 - 4 } & Cost of Poor Quality (COPQ) & .605 & 8 \\
\hline
\end{tabular}

Table 2. Statistics

\begin{tabular}{|c|c|c|c|c|}
\hline Statistics & six sigma & $\begin{array}{c}\text { Operational Efficiency } \\
\text { and Effectiveness (OEE) }\end{array}$ & $\begin{array}{c}\text { Knowledge } \\
\text { Making (KM) }\end{array}$ & $\begin{array}{c}\text { Cost of Poor } \\
\text { Quality (COPQ) }\end{array}$ \\
\hline Valid & 30 & 30 & 30 & 30 \\
\hline Missing & 0 & 0 & 0 & 0 \\
\hline Mean & 98.07 & 47.37 & 19.57 & 28.23 \\
\hline Std. Deviation & 15.045 & 8.560 & 5.488 & 3.471 \\
\hline Skewness & .051 & -.363 & -.301 & .171 \\
\hline $\begin{array}{c}\text { Std. Error of } \\
\text { Skewness }\end{array}$ & .427 & .427 & .427 & .427 \\
\hline Kurtosis & -.305 & 1.067 & .329 & .902 \\
\hline $\begin{array}{c}\text { Std. Error of } \\
\text { Kurtosis }\end{array}$ & .833 & .833 & .833 & .833 \\
\hline Minimum & 71 & 23 & 6 & 20 \\
\hline Maximum & 129 & 63 & 30 & 36 \\
\hline
\end{tabular}


Table 3. The Correlation between Dependent and Independent Variables

\begin{tabular}{|c|c|c|c|c|c|c|}
\hline \multicolumn{2}{|c|}{ Variables } & \multicolumn{3}{|c|}{$\begin{array}{c}\text { Dimensions diagnosis of } \\
\text { sustainable competitive advantage }\end{array}$} & \multirow{2}{*}{$\begin{array}{c}\text { Total diagnosis of } \\
(\mathbf{O E E}),(\mathrm{KM}) \text { and } \\
(\mathbf{C O P Q}) \\
0.922^{* *} \\
0.001\end{array}$} & \multirow[b]{2}{*}{$\begin{array}{l}\text { Rs } \\
\text { Sig }\end{array}$} \\
\hline \multirow{6}{*}{$\begin{array}{l}\text { Six sigma } \\
\text { Methodology }\end{array}$} & D & $\begin{array}{c}\text { (OEE) } \\
0.634^{* *} \\
0.000\end{array}$ & $\begin{array}{c}0.626^{* *} \\
0.000\end{array}$ & $\begin{array}{c}\text { (COPQ) } \\
0.568^{* *} \\
0.001\end{array}$ & & \\
\hline & $\mathbf{M}$ & $\begin{array}{c}0.350^{*} \\
0.058\end{array}$ & $\begin{array}{c}0.399 * \\
0.029\end{array}$ & $\begin{array}{c}0.577^{* *} \\
0.001\end{array}$ & $\begin{array}{c}0.817^{* *} \\
0.000\end{array}$ & $\begin{array}{l}\text { Rs } \\
\text { Sig }\end{array}$ \\
\hline & $\mathbf{A}$ & $\begin{array}{c}0.498^{* *} \\
0.005\end{array}$ & $\begin{array}{c}0.561^{* *} \\
0.001\end{array}$ & $\begin{array}{c}0.483^{* *} \\
0.007\end{array}$ & $\begin{array}{c}0.782 * * \\
0.000\end{array}$ & $\begin{array}{l}\text { Rs } \\
\text { Sig }\end{array}$ \\
\hline & I & $\begin{array}{c}0.592^{* *} \\
0.001\end{array}$ & $\begin{array}{c}0.615^{* *} \\
0.000\end{array}$ & $\begin{array}{c}0.686^{* *} \\
0.000\end{array}$ & $\begin{array}{c}0.759 * * \\
0.000\end{array}$ & $\begin{array}{l}\text { Rs } \\
\text { Sig }\end{array}$ \\
\hline & C & $\begin{array}{c}0.466^{*} \\
0.009\end{array}$ & $\begin{array}{c}0.468^{* *} \\
0.009\end{array}$ & $\begin{array}{c}0.539 * * \\
0.002\end{array}$ & $\begin{array}{c}0.714^{* *} \\
0.001\end{array}$ & $\begin{array}{l}\text { Rs } \\
\text { Sig }\end{array}$ \\
\hline & $\begin{array}{l}\text { Total Six sigma } \\
\text { DMAIC }\end{array}$ & $\begin{array}{c}0.815^{* *} \\
0.000\end{array}$ & $\begin{array}{c}0.930^{* *} \\
0.000\end{array}$ & $\begin{array}{c}0.667^{* *} \\
0.000\end{array}$ & $\begin{array}{c}0.678^{* *} \\
0.000\end{array}$ & $\begin{array}{l}\text { Rs } \\
\text { Sig }\end{array}$ \\
\hline
\end{tabular}

$* *$ significant $<0.01, *$ significant $<0.05$

Table 4. Regression Analysis

\begin{tabular}{|c|c|c|c|c|c|c|c|c|}
\hline \multirow[t]{2}{*}{ Model } & \multirow{2}{*}{$\begin{array}{l}\text { Adjusted } \\
\text { R Square }\end{array}$} & \multirow{2}{*}{$\begin{array}{l}\text { Std. Error of } \\
\text { the Estimate }\end{array}$} & \multirow[t]{2}{*}{$\mathbf{F}$} & \multirow[t]{2}{*}{ Sig. } & \multicolumn{2}{|c|}{$\begin{array}{c}\text { Unstandardized } \\
\text { Coefficients }\end{array}$} & \multicolumn{2}{|c|}{$\begin{array}{c}\text { Standardized } \\
\text { Coefficients }\end{array}$} \\
\hline & & & & & $\mathrm{B}$ & Std. Error & Beta & Sig. \\
\hline OEE & .802 & .37858 & $118.815^{* *}$ & .000 & $\begin{array}{l}-.383- \\
1.104\end{array}$ & $\begin{array}{l}.370 \\
.101\end{array}$ & $.900 * *$ & .000 \\
\hline $\mathbf{K M}$ & .834 & .38551 & $146.718^{* *}$ & .000 & $\begin{array}{c}-1.122- \\
1.249\end{array}$ & $\begin{array}{l}.377 \\
.103 \\
\end{array}$ & $.916^{* *}$ & .000 \\
\hline COPQ & .665 & .31634 & $58.607 * *$ & .000 & $\begin{array}{l}1.505 \\
.648\end{array}$ & $\begin{array}{l}.310 \\
.085\end{array}$ & $.823 * *$ & .000 \\
\hline SCA & .589 & .40959 & $42.475^{* *}$ & .000 & $\begin{array}{l}1.064 \\
1.064\end{array}$ & $\begin{array}{l}.401 \\
.401\end{array}$ & $.776^{* *}$ & .000 \\
\hline
\end{tabular}

$* *$ significant $<0.01, *$ significant $<0.05$.

Predictors: (Constant), Six Sigma 


\section{Six Sigma Methodology}

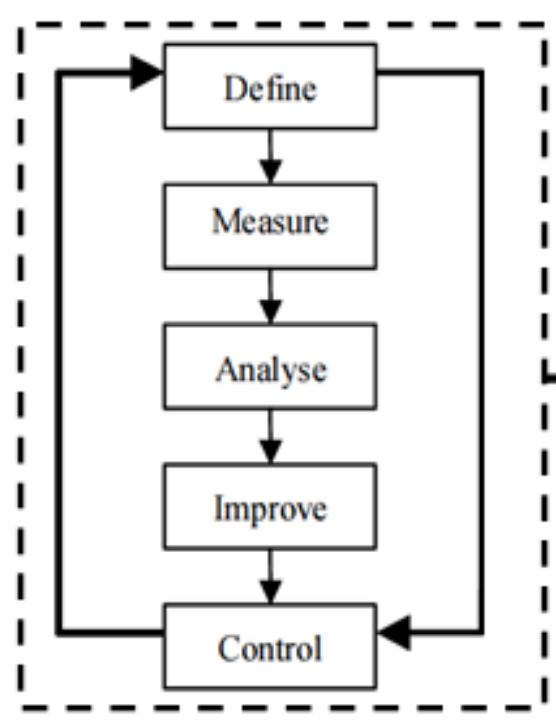

Operational Efficiency

\& Effectiveness (OEE)

Knowledge Making

(KM)

Cost of Poor Quality

(COPQ)

Figure 1. A Procedural Scheme of Study 